cepcji dla edukacji współczesnej, stąd trafnośc podjętej tematyki. Autorka udowadnia, że cele treści i metody nauczania w obecnej edukacji oraz w edukacji historycznej, sa konwergentne.

Celem artykułu Krystyny Wszołek jest rozpoznanie możliwości zastosowania idei oceny szkolnej Kazimierza Sośnickiego jako źródła analizy i oceny zjawisk obserwowanych w okresie Drugiej Rzeczypospolitej oraz obecnie. W pracy wyeksponowana została użyteczność koncepcji oceniania uczniów K. Sośnickiego w opisie i porównywaniu współczesnych podejść do zagadnień oceniania uczniów. K. Sośnicki ocenianie uczniów rozumiał bardzo szeroko i nowocześnie, był otwarty na wiele różnorodnych rozwiazań, co tym bardziej czyni jego koncepcję ważną dla współczesności. Szkoda tylko, jak trafnie zauwa- ża autorka, że myśl K. Sośnickiego nie miała wiekszego wplywu na tworzone obecnie projekty w zakresie oceny ucznia.

Podsumowując dokonaną powyżej analizę publikacji, należy stwierdzić, że wszystkie zawarte $w$ niej teksty są oryginalne $i$ zasługuja na uznanie, zwłaszcza w dobie reform oświatowych, jakie wciąz dokonuja się w Polsce. Jest to książ ka, która w sposób wyraźny zaznacza swoja praktyczna użyteczność. Należy wyrazić nadzieje. że pozycja ta będzie interesujaca $\mathrm{i}$ pożyteczna zarówno dla profesjonalistów poszukujacych obecnie nowego modelu dydaktyki ogólnej, jak i osób zajmujących się dydaktyką teoretycznie i praktycznie zorientowaną.

Justyna Gulczyńska

\title{
Juliusz Jundziłł, Wzorce i modele wychowania w rodzinie rzym- skiej w okresie III w. p.n.e. - III w. n.e., Bydgoszcz 2001, ss. 321
}

Badania historii rodziny, zwłaszcza w odleglejszej przeszłości, starożytności czy średniowieczu, nie maja w polskiej historiografii wielkich tradycji. Na Zachodzie natomiast problematyka ta od drugiej połowy lat siedemdziesiatych była intensywnie uprawiana, głównie w aspektach badania życia codziennego, w tym także codziennej egzystencji rodzinnej, uwarunkowań funkcjonowania rodziny oraz relacji zachodzacych między nią a spoleczeństwem.

$\mathrm{Na}$ naszym gruncie pierwszą książką poświęcona dziejom wychowania w rodzinie w epoce starożytnej, a rzymskiej w szczególności, była praca Juliusza Jundziłła pt. Teoretyczne problemy wychowania $w$ rodzinie rzymskiej (III w. p.n.e. - III w. n.e.), Bydgoszcz 1987. Kilkanaście lat, jakie minęły od tego czasu, w pełni uzasadniaja jej ponowne wydanie. Tym bardziej, że Autor zmieniając tytuł nowego wydania, gruntownie książkę poprawił, uaktualniając jej treść z punktu widzenia najnowszych badań w zakresie tej problematyki, pisząc niektóre partie książi wręcz od nowa.

Nowo wydana książka ma tym większe znaczenie, iż nadal w literaturze przedmiotu nie mamy do czynienia $\mathrm{z}$ szersza penetracja zagad- nienia wychowania rodzinnego $\mathrm{w}$ Rzymie (jak i zreszta w Grecji), nie wspominając o podejściu teoretycznym. Przedstawiona tu książka stanowi więc dopełnienie zachodniego nurtu badawczego reprezentowanego przez takich historyków, jak np.: K. Bradley, J. Néuraudau, B. Rawson i S. Treggiari.

Monografia składa się ze wstępu, pięciu rozdziałów oraz zakończenia, bibliografii, indeksu i streszczenia w języku angielskim. Prezentowane $w$ niej badania dotycza funkcjonowania rodziny rzymskiej, od okresu rozkwitu Republiki po czasy schyłku Wczesnego Cesarstwa. Autor wychodzi od pogladów na wychowanie w rodzinie w czasach hellenistycznych a następnie omawia poglaady Cycerona, jednego $z$ najwybitniejszych autorytetów moralnych i filozoficznych ostatniego wieku Republiki. Następnie analizie poddano zespół zapatrywań na wychowanie $w$ rodzinie powstały w okresie przejściowym od Republiki do Cesarstwa, czyli w czasie pryncypatu Augusta, przelomowego dla formowania poglądów na temat rodziny i wychowania doby Cesarstwa. Dwa ostatnie rozdziały omawiaja poglądy stoik6w rzymskich oraz odzwierciedlenie tych problemów w historiografii i literaturze pięknej. 
Autor omawia wszelkie aspekty zwiazane $\mathrm{z}$ pogladami na temat wychowania, a więc okres niemowlęcy i dziecięcy, relacje rodzice a dzieci, funkcję wychowawczą ojca, rolę matki, znaczenie wzoru przodków, miejsce rodziny w strukturze państwa. Czytelnik uzyskuje więc pełny $\mathrm{i}$ kompetentny zarys problematyki, $\mathrm{z}$ należytym uwzględnieniem wymienionych $w$ tytule wzorców i modeli. Model jest tu rozumiany jako zespół względnie uporządkowanych poglądów na dane zjawisko, wyrażanych dla potrzeb recenzowanej pracy przez autorów dzieł literackich i naukowych. Nie były one przez Rzymian do końca konsekwentnie konstruowane według współczesnych wymogów stawianych teoriom, niemniej jednak tworzą swoiste całości. W ogóle $z$ badań J. Jundzilła wynika, że Rzymianie nie tworzyli zwartych, filozoficznych teorii życia i wychowania rodzinnego, w zamian za to nawarstwiajac kolejno, według potrzeb, weryfikowane stopniowo poglądy.

Na uwage zasługuje także powiększona i zmieniona $w$ porównaniu $z$ pierwszym wydaniem bibliografia. Uzmysławia nam ona przede wszystkim, jak bardzo problematyka rodziny w szerokim znaczeniu słowa obecna jest $w$ badaniach światowych. $\mathrm{Z}$ kolei obszerne streszczenie w języku angielskim może pomóc, by ksiażka dotarła do badaczy nie znających naszego języka.

Recenzowana praca, oprócz swej całej warstwy merytorycznej, ma także wartość w postaci prowokowania do dalszych badań szczegółowych dotyczących nie tylko wychowania w rodzinie, ale $i$ jej ogólnego funkcjonowania oraz znaczenia w różnych aspektach. Może posłużyć do badań nad poszczególnymi okresami lub rodzajami źródeł, jak choćby powieść czy obrazy satyryczne, czy też nawet regionalnymi różnicami wynikajacymi ze swoistości tradycji kulturowych. Brakuje takiego podejścia badawczego zarówno u nas, jak i za granica. Ksiażka J. Jundziłła umożliwia także studia porównawcze nad zapatrywaniami i funkcjonowaniem rodziny $w$ innych kulturach starożytnych, zwłaszcza greckiej, ale i wczesnochrześcijańskiej. Niezależnie od jej wysokich walorów naukowych, należy sądzić, że recenzowana książka będzie dalej użyteczna, jak dotychczas, także dla dydaktyki na studiach historycznych, pedagogicznych i w ramach nauk o rodzinie.

Krzysztof Jakubiak

\section{Jan Konefał, Działalność społeczno-polityczna Aleksandra Za- wadzkiego (Ojca Prokopa) w Królestwie Polskim 1876-1917, Lublin 2000, ss. 205}

Myśl polityczna przełomu XIX i XX wieku została już w zasadzie opracowana, dużo mniej jest natomiast prac ukazujących, kto $\mathrm{i}$ jak idee społeczno-polityczne tych czasów próbowal realizować w praktyce. Ksiażka stara się lukę tę uzupełnić i dlatego też jej wydanie należy przyjać z zadowoleniem.

Przedstawiona tu monografia składa się ze wstępu, 6 rozdziałów, zakończenia, bibliografii, wykazu skrótów, indeksu nazwisk i 20 aneksów. Autor, w porządku chronologicznym, ukazuje imponujaca doprawdy aktywność społeczno-polityczną i oświatowa „ojca Prokopa”. Nie widzę jednak specjalnej potrzeby, aby działalności wydawniczej bohatera książki podczas I wojny światowej poświęcać osobny rozdział, jak to uczynił Autor omawianej pracy, tym bardziej, że rozdział ten liczy niespełna 9 stron. Jego treści można by umieścić $w$ rozdziale poprzednim, odnoszącym się do tego samego zreszta okresu, nadając mu tym samym bardziej wyrazisty charakter.

Pierwsze rozdziały opracowania J. Konefała sa nie tylko bardzo wartościowe, ale i ciekawe, jednakże rozdziały ostatnie (V i VI) są już mniej interesujace, zaś duża liczba nazw, skrótów, nazwisk i dat utrudnia ich lekturę. Różnice programowe partii ludowych w początkach $\mathrm{XX}$ wieku były niewielkie, a ich programy spoleczno-wychowawcze podobne, co nie ułatwiało Autorowi zadania $w$ trakcie ich przedstawiania. Niezbyt jasno przedstawił on również zmiany politycznej orientacji Zawadzkiego $w$ jego dojrzałym wieku. Uwagę tę można zreszta odnieść do calego okresu jego politycznej aktywności. Zmiany ideologicz- 